\title{
A DISPUTE OVER THE PHILOSOPHY OF CLOTHES. CYPRIAN NORWID VERSUS THOMAS CARLYLE
}

After a longer while, on the occasion of reviews and discussions of Kalendarz życia i twórczości Cypriana Norwida, it has become possible to reconsider the largely unacknowledged parallel between the aesthetics and anthropology of Cyprian Norwid and the philosophical worldview of Thomas Carlyle. On the one hand, Elżbieta Lijewska diminishes the significance of the theme that is fundamental for researching the influence that Carlyle supposedly had on Norwid. She does so by rightly pointing out the error in Kalendarz... regarding the identity of Katherine Kitty Kierkpatrick, who used to exchange letters with Norwid. So far, she was assumed to be Carlyle's lover from the time he was writing Sartor Resartus. However, the mysterious Kierkpatrick is most probably Norwid's cousin, Ketty Kleczkowska-Kierkpatrick. ${ }^{1}$

On the other hand, we may follow Bogdan Burdziej, who recalls and closely analyses the context of the letter from Marian Sokołowski to Norwid, dated 10 July 1861, regarding Wykłady o Juliuszu Stowackim [Lectures on Juliusz Stowacki]. Sokołowski allegedly compares in it "elements of the poet's style and thought with those encountered in texts by Thomas Carlyle and Percy Bysshe Shelley." According to Burdziej, "the way in which Sokołowski formulates his opinion ('You remind me of certain abstract passages from Thomas Carlyle [...]') confirms his belief that Norwid had sufficient knowledge of works by both authors in order to fully understand the comparison made by the author of the letter." ${ }^{\prime 3}$ As

${ }^{1}$ E. LiJewsKa, Kuzynki Norwida. Euphemia Tudor Kleczkowska i Ketty Kleczkowska-Kierkpatrick, "Studia Norwidiana" 34 (2016), pp. 169-185.

2 B. BuRDZIEJ, 'Wedle rozmaitości zmiennej kalendarza'. Norwid 'przemyślony', "Studia Norwidiana" 34 (2016), p. 203.

${ }^{3}$ Ibid. 
Burdziej suspected in relation to this, "Norwid could have come into contact with Carlyle as the author of an introduction to essays by R.W. Emerson, whose writings he probably knew." "It is worth adding that Burdziej's explorations dovetail with the broad considerations of Stanisław Brzozowski, who was the first to suggest - in Legenda Mtodej Polski [Young Poland's Legend] - the existence of a parallel between Norwid and Carlyle:

It would be very helpful to awaken and develop among the Poles a "historical passion," which I understand as love and respect for all works and processes of communal human life that transcend individual existence. It is necessary to nourish and exercise a sense of, and a passion for great rhythms, which are larger than any single person. Vico, Michelet, and Carlyle seem to be the most appropriate authors to ignite it. A solid, annotated edition of Norwid would be also invaluable in this respect. ${ }^{5}$

According to the authors of Kalendarz życia i twórczości Cypriana Norwida, Norwid read works by Ralph Waldo Emerson (his essays or the treatise Representative Men) as late as in the years $1853-1854 .{ }^{6}$ Possible reminiscences from

4 Ibid.

${ }^{5}$ S. Brzozowski, Literatury zachodnie, [in:] IDEM, Legenda Młodej Polski. Studia o strukturze duszy kulturalnej. Redakcja II, vol. 1: eds. J. Bahr, S. Góra; vol. 2: ed. T. Podoska, Kraków 1997, p. 286. It is worth to note the very subtle remarks (left in potentio) made by Brzozowski in this passage. If Norwid is to appear next to Vico, Michelet and Carlyle, he needs a good edition with proper annotations. One should not ignore any such scruples in Legenda Młodej Polski. Brzozowski did not choose Norwid before Carlyle as his partner in dialogue. It suffices to say that Brzozowski himself was very inconsistent in choosing the Polish adherents of Carlyle, claiming either that there is no one deserving to be called the "Polish Carlyle," as argued in "Polskie Oberammergau": "Given the character of Polish literature so far, it seems impossible to conceive within it any Hebbel, Balzac, Kleist, Carlyle, or Machiavelli," or that it could be only one person: Stanisław Wyspiański, as argued in Wobec literatury rosyjskiej: "In his own society, Dostoevsky was what Carlyle was to the British, Carducci for Italians, and Wyspiański for Poles." Norwid does not really appear in such enumerations next to Carlyle. S. Brzozowski, Polskie Oberammergau, [in:] Legenda Młodej Polski, vol. 1, p. 181; IDEM, Wobec literatury rosyjskiej, [in:] Legenda Młodej Polski, vol. 2, p. 349.

${ }^{6}$ Z. Trojanowiczowa, Z. DAMBeK, Kalendarz życia i twórczości Cypriana Norwida, vol. 1: 1821-1860, Poznań 2007, p. 549. In Norwid studies there dominates the belief that Norwid's ethos of great historical figures draws - if we are to seek its broad influences - rather form Emerson's Representative Men than from Carlyle's On Heroes, Hero-Worship, and The Heroic in History. As George Gömöri notes, "[t]here could be certain things which linked Norwid to Emerson. They were both Abolitionists and both believed in the special destiny of 'representative individuals'." G. GöмÖRI, "Cyprian Norwid's Image of England and America," The Polish Review 2001, vol. 46, no. 3, p. 279. Carlyle's views on this had to seem pro-slavery, as confirmed by the 1849 essay "Occasional Discourse on the Negro Question" and the debate with John Stuart Mill, who responded to Carlyle'a text in 1850 with "The Negro Question." 
reading Carlyle, however, may go back even to Promethidion, where Wiesław challenges in the second dialogue the views of Diogenes Teufelsdröckh, hero and ideological protagonist of the novel Sartor Resartus, meticulously imagined and developed creator of sartorial philosophy': "Czar papieży / Ile z zewnętrznej pochodzi przyczyny / Z szat drogich, pawich piór i pajęczyny / Koronek - również do niego [szatana] należy -" [The charm of the popes / Stems from external matters: / Rich attire, peacock feathers, lacy / Spiderweb - all of this also belongs to him $\{\operatorname{Satan}\}]$ (DW IV, 126).

As the following passage from Promethidion makes it clear,

Nie idzie tu i w całym zewnętrzności pojęciu o zdarcie drogości, świetności, błyskotności, ale o proporcję ich z powagą wewnętrzną, rzeczywistą - ale o strawienie ich na sobie powagą życia - bo i tak duch ma dosyć ciężaru w szacie ciała!... Na cóż go jeszcze obciążać ciałem szaty?... [The point about external appearance is not that one should eliminate all richness, splendour and brilliance, but rather balance them with actual internal solemnity - to achieve poise between them and existential seriousness - since the spirit is already burdened with its bodily form!... Why would one want to drag it down even more with robes?...] (DW IV, 126)

What emerges here is a clear polemic with chapter six from book three in Sartor Resartus:

The gladder am I, on the other hand, to do reverence to those Shells and outer Husks of the Body, wherein no devilish passion any longer lodges, but only the pure emblem and effigies of Man: I mean, to Empty, or even to Cast Clothes. Nay, it is not to Clothes that most men do reverence: to the fine frogged broad-cloth, nowise to the "straddling animal with bandy legs" which it holds, and makes a Dignitary of? Who ever saw any Lord my-lord in tattered blanket fastened with wooden skewer? Nevertheless, I say, there is in such worship a shade of hypocrisy, a practical deception: for how often the Body appropriate what was meant for the Cloth only! ${ }^{8}$

Sartor Resartus - written by Carlyle between November 1833 and August 1834 - is, one might say, a parody of a Romantic novel contained within a parody of an idealistic and historiosophic treatise. The narrator is a reviewer staying at the house of Diogenes Teufelsdröckh. Despite their closeness, the former cannot understand the reason why Teufelsdröckh decided to write an extravagant treatise on sartorial philosophy and (to follow Hegel) a "phenomenology" of attire and dressing. Along with the editor's increasing liking for the wild ideas of a "clothing

${ }^{7}$ One work that is very important for sartorial philosophy and its impact in Poland as an element of modernist intellectual fashion is the synthetic monograph by Anna Małecka titled Carlylean inspirations in Polish modernist philosophy (Kraków 1993).

${ }^{8}$ T. CARLYLE, Sartor Resartus. On heroes, hero worship, London 1948, p. 180. 
idealist," the perspective of reviewing his opus magnum is fading, while readers become more and more aware of the eccentric man's past, which led him to the seemingly pitiful "here and now." In the context of its playful relation to the preRomantic paradigm, the crucial aspect of Sartor Resartus seems to consist in the poor man's fascination with Blumina (a possible model for Kierkpatrick), who ultimately chooses not Teufelsdröckh but the affluent Towgood. As is clear, in Carlyle's book the story is vestigial - what determines its real value is its character of a treatise. As for the onset of the story, it is of crucial importance why the situation encountered by the reviewer occurs in the prologue: a banal, Wertherian story seen in a distorting mirror provides an intellectual impulse to Teufelsdröckh, who embraced it without inhibition and created an absurd (though enthralling) pseudo-Hegelian treatise on clothing.

Whereas the rich semantic landscape of Promethidion can be argued to reveal Norwid's polemical disposition towards Sartor Resartus, which was clearly unfavourable or perhaps even marked by a "gesture of negation and rejection," Carlyle's work seems to return three decades later in Norwid's so-called Italian novellas (written at a notably significant time, i.e. soon after Carlyle's death in 1881) as an object of "coded" affirmation. It is particularly Tajemnica lorda Singelworth [Lord Singleworth Secret] that appears to actually revisit the sartorial philosophy featured in one of the more significant digressions in Promethidion. The peculiar lord-aeronaut appears to be modelled on Diogenes Teufelsdröckh from Sartor Resartus. His eccentricities may also recall those of Carlyle himself from his forties and fifties, as remembered by Ralph Waldo Emerson, who must have been important to Norwid.

Clearly, the body of discussions concerning the identity of Lord Singelworth has grown to such an extent that all relevant comments cannot be either exhaustively listed or addressed here. However, it suffices to recall that in one of the last texts on the subject - Tajemnice 'Tajemnicy lorda Singelworth' by Zofia DambekGiallelis - the author indicates Norwid's possible inspiration with the figure of Dionizos Solomos from Podróż do Ziemi Świętej z Neapolu due to the similarity between models of "creative eccentricity" followed by Słowacki and Norwid. She writes:

The most interesting aspect of Singelworth's persona is his studied eccentricity, which is supposed to appear as something natural: avoidance of company, compulsive cleanliness, and isolation from the world; these features bring to mind one portrait of a poet that could have stuck in Norwid's memory, namely the ironic characteristic of the Greek poet Dionizos Solomos sketched in Podróż do Ziemi Świętej z Neapolu by Juliusz Słowacki. We can assume that Norwid read the 
long poem by Słowacki, which was published posthumously by Antoni Małecki in $1866 .^{9}$

The emphasised, "studied eccentricity" - which Dambek-Giallelis found so engaging, and which recurs also in other studies touching upon Norwid: comparisons (1) between Singelworth and Byron (by Grażyna Halkiewicz-Sojak ${ }^{10}$ ), or (2) between Singleworth and famous dandies (by Krzysztof Trybuś, who draws a parallel between Norwid's novella and the Venetian long poem Beppo ${ }^{11}$ ) - is, in terms of a clear symmetry of types, also a "studied eccentricity" on the part of Carlyle, especially when read through the prism of Emerson, i.e. following the famous study of Carlyle, which Norwid could know - Impressions of Thomas Carlyle in 1848. In it we can read:

1. [Carlyle] is also as remarkable in England as the Tower of London, yet neither would he in any manner satisfy us (Americans).

2. They keep Carlyle as a sort of portable cathedral-bell, which they like to produce in companies where he is unknown, and set a-swinging, to the surprise and consternation of all persons, bishops, courtiers, scholars, writers [...].

3. He is obviously greatly respected by all sorts of people,--understands his own value quite as well as Webster, of whom he his behavior sometimes reminds me,- - and can see society om his own terms.

4. If you would know precisely how he talks, just suppose Hugh Whelan (the gardener) had found leisure enough in addition to all his daily work to read Plato and Shakespeare, Augustine and Calvin, and, remaining Hugh Whelan all the time, should talk scornfully of all this nonsense of books that he had been bothered with [...].

5. I called him a trip-hammer with an "Aeolian attachment.",12

Clearly, Singelworth was a lord, while Carlyle - as Emerson claimed, though he was not alone in this - was "a practical Scotchman, such as you would find in any saddler's or iron-dealer's shop, and then only accidentally, and by a surprising addition, the admirable scholar and writer he is." ${ }^{13}$ One therefore needs to keep in mind that the enigmatic title of Norwid's protagonist was also questioned. "Czyli raczej Singelworthowie byli zacnymi właścicielami rękodzielni wyrabiających perkaliki albo rzeczy cynowe i stalne?..." (DW VII, 214) [Or

9 Z. Dambek-Giallelis, Tajemnice 'Tajemnicy lorda Singelworth', "Studia Norwidiana” 35 (2017), p. 195.

${ }^{10}$ G. Halkiewicz-SojaK, Norwidowska legenda o Byronie. Refleksy legendy w innych utworach Norwida, [in:] IDEM, Byron w twórczości Norwida, Toruń 1994, pp. 112-113.

${ }^{11}$ K. Trubuś, Maska lorda Singelworth, "Studia Norwidiana” 14 (1996), p. 101.

12 R.W. EMERson, Impressions of Thomas Carlyle in 1848, "Scribner's Monthly", May 1881, p. 89. After: https://hdl.handle.net/2027/coo.31924079637470 (accessed 17 January 2021).

13 Ibid. 
would it be safer to say that the Singelworths were the respectable owners of a dry-goods mill or a factory that made products of tin and steel $\left.?^{14}\right]$ asks the narrator already in the novella's fifth sentence (both rhetorically and contrarily), the question conveying some of the eponymous mystery of the (non-) lord-aeronaut's "studied eccentricity." To make it clear, James Carlyle, father to Thomas, was a stonemason, while his second wife and mother to Thomas was the daughter of an impoverished farmer distressed by losing his property in Dumfriesshire. ${ }^{15}$

In his balloon journey along the trail of European capitals, Singelworth performs a vivisection of the modern civilization. Just like the Scottish author, he is a ruthless murderer of many "modern illusions." As Sygurd Wiśniowski observed, "Carlyle's scathing sense of humour and fiery speech made him a desirable yet formidable author and guest." ${ }^{16}$ The Polish populariser of Carlyle - who would cause panic among the English - and translator of Sartor Resartus also argues triumphantly (biased against the English) that "in England this commoner carried on with pride, making the rich, fashionable and powerful world to tremble before him." ${ }^{17}$ In Norwid's work, the abusiveness of Singelworth is merely suggested, but it becomes striking and suggestive when he compares "continental Europeans" with black Africans because ze wszystkiego się śmieja, czego od razu pojać nie sq $w$ stanie (DW VII, 229) [they share with the Africans their mockery at anything they are incapable of grasping $\left.{ }^{18}\right]$ or when - considering the dualism of good and

14 O. SCHERER-VIRSKI, The Modern Polish Short Story, Hague 1955, p. 54.

${ }^{15}$ Born of "peasant parents" - as Wiśniowski writes - Carlyle was the son of "a farmer and a mason bungler.” S. WiŚniowski, “Tomasz Carlyle,” [in:] T. CARlyle, Sartor Resartus, p. 5. Here we touch upon the very heart of the debate between Carlyle and the American transcendentalists, especially Emerson (as indirectly shown in Impressions of Thomas Carlyle in 1848). It was a debate between aristocrats and plebeians, "a gentleman from New England" (Stefan Bratkowski's terms) and "a critically-minded Scotsman of peasant origin" (Sygurd Wiśniowski's term). As for Emerson, "after the initial period of wandering through various forms of individualism [...] his philosophy had little to do with the aristocratism of Carlyle, Spencer or Nietzsche. It was plebeian in essence and purpose. Emerson addressed it to millions of his compatriots, millions of American self-mademen.” S. BratKowsKi, Wstęp, [in:] R.W. EMERSOn, Eseje, trans. A. Tretiak, vol. 1, Lublin 1997, p. 21. If Tajemnica lorda Singelworth seems to reveal the impact of Carlyle's aristocratism on Norwid, the possible influence of Emerson's plebeianism (and perhaps of Walt Whitman's poems) is revealed in A Dorio ad Phrygium. See: F. CorLIss JR., Norwid and the American Transcendentalists, [in:] Cyprian Norwid. 1821-1883. Poet, thinker, craftsman. A centennial conference, eds. B. Mazur, G. Gömöri, London 1988, pp. 74-75.

${ }^{16}$ S. Wiśniowski, Tomasz Carlyle, p. 7.

17 Ibid., p. 8.

${ }^{18}$ O. SCHERER-VIRSKI, The Modern Polish Short Story, p. 60. 
evil that Europe still seemed to condone - he argues that "it is among the people, just like among some generations in the Caucasus" (DW VII, 230). ${ }^{19}$ Singelworth usurps the unique right to hurl accusations out of the belief that - as the only one or one of the few - he "looks down upon" all culture and civilization, doing so (out of necessity) with superiority because he is in fact looking into a septic tank.

The perspective of a sharp, domineering and judgemental panorama is also inextricably embedded in Teufelsdröckh's reflections and meditations from Sartor Resartus. Just like Singelworth would train himself to look down on everything from his balloon, Teufelsdröckh used elevated lodgings as a "speculum or watchtower." "Wherefrom," Carlyle continues, "sitting at ease, he might see the whole life-circulation of that considerable City; the street and lanes of which, with all their doing and driving (Thun and Treiben), were for the most part visible there."21 Let us compare relevant passages:

\begin{tabular}{|c|c|}
\hline C. Norwid, Tajemnica lorda Singelworth & T. Carlyle, Sartor Resartus \\
\hline $\begin{array}{l}\text { “Tymczasem miasta wasze, siedziby } \\
\text { i społeczności sklepią się, budująi rozwijaja } \\
\text { na kloakach... Te wykwintne kuchnie, które } \\
\text { co dnia pod wieczór buchają aromem won- } \\
\text { nych przypraw i sosów, maja pod posadz- } \\
\text { kami swoimi trzęsawiska zgnilizny - te } \\
\text { ponętne błyskotem swym i elegancją salo- } \\
\text { ny, gdzie równie lekki jak zefir trzewik ta- } \\
\text { necznicy walcuje z zefirem, one są usklepio- } \\
\text { ne na podziemiach ciężkich i odrażających. } \\
\text { Leniwe tam ramię rozkładającego się ol- } \\
\text { brzyma przeciąga się, ale nieustającą walkę } \\
\text { co dnia i co chwila toczy - coś, jakby wciąż } \\
\text { gnijacy Laokoon, przewraca się w piecza- } \\
\text { rach stolic pod umiecionymi gładko ulica- }\end{array}$ & $\begin{array}{l}\text { "'I look down into All that wasp-nest or bee- } \\
\text { hive', have we heard him say, 'and fitness their } \\
\text { wax-laying and honey-making, and poison- } \\
\text { brewing, and choking by sulphur. From the } \\
\text { Palace esplanade, where music plays while } \\
\text { Serene Highness is pleased to eat his victuals, } \\
\text { down to the low lane, where in her door-sill the } \\
\text { aged widow, knitting for a thin livelihood, sits } \\
\text { to feel the afternoon sun, I see it all'." "Their } \\
\text { solid Pavement is a Picture of the Sense; they } \\
\text { walk on the bosom of Nothing, blank Time is } \\
\text { behind them and before them." "Oh, under that } \\
\text { hideous covelet of vapours, and putrefactions, } \\
\text { and unimaginable gases, what a Fermenting- } \\
\text { vat lies simmering and hid!" }\end{array}$ \\
\hline
\end{tabular}

${ }^{19}$ Singelworth's behaviour, which may suggest racism, chauvinism, or nationalist prejudice, can be explained in reference to Carlyle's biography, especially in light of his essay "Occasional Discourse on the Negro Question." It would be another argument in favour of the hypothesis that Norwid modelled Singelworth (along with his idiosyncrasies or perhaps foregrounding on them) on Carlyle. See also note 5.

20 T. CARLYLE, Sartor Resartus. On heroes, p. 14.

${ }^{21}$ Ibid. 


\begin{abstract}
mi!..." (DW VII, 230; emphasis added) [Meanwhile your cities, dwellings and societies are founded, built and developed above a system of latrines. A mud of putrefaction lies underneath those elegant kitchens, from which every evening a fragrant aroma of seasoning and sauces emanates. The drawing-rooms, attractive in their splendor and elegance, where a lady's shoe waltzes as light as Zephyr, are built above heavy and repulsive basements. The giant of decay stretches his arms, and a ceaseless war is waged at every moment of the day; it is something like a putrescent Laocoon, turning over and over in the cellars of every capital city under the neatly swept streets. ${ }^{23}$ ]
\end{abstract}

"Odpowiednia doza perfum gdy staje w przeciwieństwie zględem dozy odpowiedniej rozkładowego fetoru, jest to dla was czystym oddechem, bo taki już macie nerwów ustrój." (PWsz VI, 158) [An appropriate doze of perfume set against a similarly strong odor of decay constitutes cleanliness of atmosphere for you, because such is the nature of your nervous system. ${ }^{24}$ ]

"- Ludzie nie sa jeszcze czyści... sa dopiero perfumowani..." (PWSz VI, 160) [People are not yet clean ... so far they are merely perfumed. ${ }^{25}$ ]
"The proud Grandee still lingers in his perfumed saloons, or reposes within damask curtains; Wretchedness Cowes into trucklebeds, or shivers hunger-stricken into its lair of straw." 26

Among the similarities between Tajemnica lorda Singelworth and Sartor Resartus the most intriguing one (and the most inconspicuous) might be the stylization of language used by Norwid's lord and Carlyle's professor, which brings to mind archaic, argotic or creole-like speech. Teufelsdröckh plastically forms his English, showing that it can or even should be made similar to his first language. He chooses archaic forms he associates with Prussia ("thee" as "die"; "couldst" as "hast" etc.) as if his English was Germanized - familiarized or domesticated -

\footnotetext{
${ }^{23}$ O. SCHERER-VIRSKI, The Modern Polish Short Story, p. 60-61.

${ }^{24}$ Ibid, p. 60.

${ }^{25}$ Ibid, p. 62.

${ }^{26}$ T. CARLYLe, Sartor Resartus. On heroes, p. 14-16.
} 
whereas in fact it is made archaic in passages like "the thing thou seekest is already with thee, 'here or nowhere', couldst thou only see!"26; "nay, in thy own mean perplexities, do thou thyself, but hold thy tongue for one day" pitifullest infinitesimal fraction of a Product. ${ }^{, 28}$ Norwid's Singelworth, on the other hand, speaks in a way that suggests using macaronics in a fashion typical for the Polish nobility of the seventeenth and eighteenth century, adopting prolix and "disjointed" syntax, almost invariably heading in his short monologues towards some grammatical mistakes. Let us consider one sentence that was "made scientific":

Lecz u tychże tak łatwo śmiejących się jest $\mathrm{w}$ zamian piękne uczucie poważania $\mathrm{z}$ wielką łatwością donośnych imion historycznych; będę więc umiał choć tym sobie posłużyć i pomóc na swoim miejscu, kiedy, w zupełny wykład celu mojej aeronaucji zapuściwszy się, napotkam gdzie trudności, na uprzedzający śmiech zwykłe wykładającego rzecz nową narażać. (DW VII, 230)

[But those people, who are so prone to laughter, possess in exchange a lofty sense of respect for, and a great facility at, recalling high-sounding historical names. I shall therefore take advantage of this propensity and try to have it serve my purposes, should I encounter any difficulties in the course of these remarks about the aims of my aeronautical practices, rather than expose my ideas to prejudiced laughter. $\left.{ }^{29}\right]$

It is also in Tajemnica lorda Singelworth that Norwid seems to revisit Carlyle's sartorial philosophy, which he first addressed in Promethidion, initiating his dispute with the outstanding Scotsman. He does not do so through the eponymous figure, who could be an aggregate of both Diogenes Teufelsdröckh and Thomas Carlyle himself, but through Toni di Bona Grazia, a Venetian improviser, who suggests to his listeners that peering into the waste heap is the only sine qua non condition of recognizing the historical principle in a world where - as Victor Hugo argues in Les Misérables and as Krzysztof Trybuś emphasises in the context of Tajemnica lorda Singelworth - "[t]he sewer is the conscience of the city" and "[a] garbage dump has this to be said for it: it doesn't tell lies."

${ }^{26}$ T. CARLYLE, Sartor Resartus. On heroes, p. 148.

${ }^{27}$ Ibid., p. 164.

${ }^{28}$ Ibid., p. 148. The suspicion of Stanisław Brzozowski was in turn aroused in Legenda Młodej Polski by the choppy syntax of Sartor Resartus. He would wonder at it and speculate about its meaning, finally concluding even that "Carlyle wrote Sartor Resartus, almost a self-partody, while Nietzsche - Zaratusthra - a dithyramb." S. BRzozowski, Humor i prawo, [in:] IDEM, Legenda Młodej Polski, vol. 1, p. 294 and elsewhere.

${ }^{29}$ O. SCHERER-VIRSKI, The Modern Polish Short Story, Hague 1955, s. 60.

${ }^{30}$ V. Hugo, Les Misérables, [in:] IDEM, The Essential Victor Hugo, trans. E.H. Blackmore, A.M. Blackmore, 
The parallel with Les Misérables is indeed intriguing in the context of Norwid, but one cannot forget about Sartor Resartus as indicated by what the improviser emphasises: "atłasowy trzewik, konwulsyjnie skręcony, opierający się na stłuczonej butelce" [a shoe, formerly of satin, now convulsively twisted and leaning against a broken bottle] and "guzik munduru wojskowego, przeświecający spod szczątków miotły" [the button of an army uniform, shining through the remains of a broom ${ }^{31}$. Both in Norwid and Carlyle, symbols of this kind - signs and remains of "robes" - are equipped with a broader horizon of history and eschatology. In Sartor Resartus, the place of Norwid's "trzewik" [a shoe] and "guzik mundurowy" [he button of an army uniform] are taken by a colourful "Clothesscreen," "spurs on its heels" and "feather in its crown":

\begin{tabular}{|c|c|}
\hline C. Norwid, Tajemnica lorda Singelworth & T. Carlyle, Sartor Resartus \\
\hline $\begin{array}{l}\text { “[..] o! świetna publiczności... jakkolwiek } \\
\text { bowiem wy! - lubo słusznie - odwracacie } \\
\text { oczy wasze od śmietników, mnie zdarzało } \\
\text { się w głębokim zadumaniu nad nimi stawać } \\
\text { i odczytywać dzieje godzin ubiegłych z tych } \\
\text { okrytych kurzawą palimpsestów. Tu były- } \\
\text { atłasowy trzewik, konwulsyjnie skręcony } \\
\text { i opierający się na stłuczonej butelce - tam } \\
\text { guzik munduru wojskowego przeświecający } \\
\text { spod szczątków miotły - ówdzie siódemka- } \\
\text { czerwienna, as treflowy i wizytowa karta, } \\
\text { połamane... dalej fiołków bukiet, który oto } \\
\text { błędna i nie dowierzająca kotka wącha... } \\
\text { w pobliżu kałamarz pusty i nadużyte pióro, } \\
\text { nieudolnie silące się podrywać z powianiem } \\
\text { wiatru!... Szczątki te śmietnicze opowiadały } \\
\text { mi były nieraz długie i zawiłe przypowieści } \\
\text { - kto wie, azali Muza moja nie była kiedyś } \\
\text { szyfonierką?!...” (DW VII, 223) } \\
\text { [Oh, illustrious audience. Although you, } \\
\text { quite lightly, turn your heads away from rub- } \\
\text { bish heaps, I have often stopped before them } \\
\text { in deep meditation to read the history of re- } \\
\text { cent hours from those dust-covered palimps- } \\
\text { ests. Here lies a shoe, formerly of satin, now }\end{array}$ & $\begin{array}{l}\text { "Or fanciest thou, the red and yellow Clothes- } \\
\text { screen yonder, with spurs on its heels and } \\
\text { feather in its crown, is but of Today, without } \\
\text { a Yesterday or a Tomorrow; and had not rath- } \\
\text { er its Ancestor alive when Hengst and Horsa } \\
\text { overran thy Island? Friend, thou seest here a } \\
\text { living link in that Tissue of History, which } \\
\text { inweaves all Being: watch well, or it will be } \\
\text { past thee, and seen no more." }{ }^{34}\end{array}$ \\
\hline
\end{tabular}

${ }^{31}$ O. SCHERER-VIRSKI, The Modern Polish Short Story, p. 57. 
convulsively twisted and leaning against a broken bottle; and there - the button of an army uniform, shining through the remains of a broom; there again a seven of hearts, an ace of clubs, and a calling card, now all torn... further on, a lost and mistrustful cat sniffing a bunch of faded violets... not far from it, an empty inkstand and a worn pen, the latter unsuccessfully trying to fly off with the wind... These rubbish heap remains have often told me long and sometimes complex tales. Who knows if this Muse of mine has not at one time been a decipherer of codes $?^{33}$ ]

In the first table, which compares Tajemnica lorda Singelworth and Sartor Resartus, certain passages are underlined, emphasising parts once used as justification by Wiktor Weintraub to formulate a categorical assessment of Norwid's entire novella. The critic accused the poet of "venting severe misanthropy through scatological humour." ${ }^{34}$ It seems that he remained moved by the precedent he identified and named. "So far," he goes on, "Norwid's sense of decorum was impeccable, while his style was elegant and refined, far from vulgarity.", 35

Weintraub's impression does not seem to be accidental. It appears to be rooted in Norwid's creative intention to enter a rivalry with Carlyle as the author of Sartor Resartus. This desire could have intensified after the death of the Scotsman on 5 February 1881 in London. It is yet another in a series events that remain part of the complex genealogy of Norwid's 1881-1883 Italian trilogy.

Finally, let us turn toward the two-part names of Norwid's and Carlyle's protagonists. "Single-worth" can refer to something of fixed value or individual. As Richard J. Bishirjian explains in "Carlyle's Political Religion," "Dio-genes Teufels-Dröckh" refers to the fact that "Man's origin is in God, and his existence is the devil's feces" ${ }^{\text {"36 }}$ - we have been created by God and God awakens in us every

32 O. SchERER-VIRSKI, The Modern Polish Short Story, p. 57.

33 T. CARLYLE, Sartor Resartus. On heroes, p. 15.

${ }^{34}$ W. Weintraub, Norwid i Ameryka, "Studia Norwidiana" 14 (1996), p. 17.

35 Ibid.

36 R.J. Bishirjian, Carlyle's Political Religion, "The Journal of Politics" 38 (1976), no. 1, p. 98. Cf. also the number of Norwid's references to the philosophy of Diogenes: A. ZIOLowicz, $W$ stronę Diogenesa. Z problemów Norwidowskiej koncepcji kultury, "Wiek XIX. Rocznik Towarzystwa Literackiego im. Adama Mickiewicza” 2015, pp. 359-378. 
day, but here on earth we are stuck in devil's excrements (another explanation of the name Teufelsdröckh is "God-born devil's excrements" ${ }^{37}$ ).

Norwid could recall this specific anagram of Carlyle's in many passages of his own, beginning with the most recognizable one from Idee i prawda [Ideas and Truth] ("I nieraz szczytne wczorajszego wieka / Dziś - tyczy kału..." [And often what's lofty in yesteryear / Today - touches excreta... ${ }^{38}$ ] (PWsz II, 66)), through longer forms, like the attempt at a theory of truth in Rzecz o wolności stowa [On the Freedom of Speech] ("Zniżona tak, zaczerpnie namiętności kału, / Potem się wyprze ojca swego... Ideatu!" [Degraded in this manner, it shall taste the passion for faeces, / Later disowning its father... the Ideal!]; DW IV, 248), and ending with the relatively least known phrases from his dramatic works, e.g. the tirade of Rizzo from Hrabina Palmyra [Countess Palmyra] ("ludzie, co tworzą dla ludzi [...] wlec się powinni w kale jak spadłe anioły" [people who create for people [...] should drag themselves in faeces like fallen angels]; DW V, 316). All of Norwid's gnomic references of this kind can be elucidated in analyses basing on the "devilish" charade from Sartor Resartus, and most can be in fact reduced to Bishirjian's claim.

In Tajemnica lorda Singelworth, in order to "usunąć nieco falangę kału" [remove a mass of excrement] one needs to "całą falangę ludzi zdegradować" [degrade a multitude of people ${ }^{39}$ ] (DW VII, 230). However, uncleanliness is a fixation shared not only by the lord but also by those who backbite or describe him, like Toni di Bona Grazia. Invoked by Singleworth, Xanthippe "wylewa z okna" [pours from a window] "urnę pełną domowych nieczystości" [an urnful of household refuse $^{40}$ ] on the forehead of Socrates (DW VII, 231). The Venetian improviser in turn asks ironically how it is possible that "ktoś nad najznakomitszymi na świecie miejscami dlatego tylko unosił się, ażeby tam warunków poziomych higieny dopełniał... ażeby (mówię) splunął z góry!..." [a person rises above the most illustrious places on earth merely to fulfil the prosaic conditions of health... only (I say) to expectorate! ${ }^{41}$ ] (DW VII, 122).

One would be inclined to say that Carlyle's paradox of "God-born devil's excrements" was basically dismantled or dispersed by Norwid - perhaps even de-

37 J. Pistelli, Thomas Carlyle, Sartor Resartus. Online: https://johnpistelli. com/2015/ 01/13/thomas-carlyle-sartor-resartus/ (accessed 22 November 2018).

${ }^{38}$ C. Norwid, Poems, translated from the Polish by Danuta Borchardt in collaboration with Agata Brajerska-Mazur, New York 2011, p. 47.

39 O. SCHERER-VIRSKI, The Modern Polish Short Story, p. 61.

40 Ibid.

${ }^{41}$ Ibid, p. 56. 
constructed - in the face of Carlyle's death. Norwid settled accounts with Carlyle posthumously, but undeniably this revision and reassessment would retain, to a considerable extent, the architecture of an elaborate reminiscence since Carlyle figures much more prominently in Tajemnica lorda Singelworth than in Promethidion (where he appears basically only in an otherwise significant digression in the dialogue Wiestaw).

Alternatively, we could regard the aforementioned digression, despite everything, as an important context to the dialogue presented in 1851. This would constitute a special contribution to Norwid's genealogy of "szatan-krwawiec" (term used in Promethidion; DW IV, 128) as well as a significant, score-settling point in the clarification of a broader metaphysical plane in this work. Could it not therefore be a clear instance (clearer than previously assumed) of Carlyle's theme of "devil's excrements" from Sartor Resartus recurring in Norwid in the form of "piętrowane peruki" [multilayered wigs] and "korki twarde" [hard, cork heel shoes], the latter being as hard as Satan's hooves (DW IV, 129)? No such recognition was made or even suggested in the history of studies on Promethidion, even in erudite elucidations of this particular digression, e.g. by Anna Kadyjewska. ${ }^{42}$ It could be worthwhile to risk establishing this kind of an intertextual relation, because in its light Norwid's great poem can appear to be an intellectual squaring of accounts in his time, also constituting - in this dimension, especially after reading Wiestaw - a response to Sartor Resartus, or even (cum grano salis) Norwid's "anti-Sartor Resartus."

Certain tropes traced by scholars studying Tajemnica ... also suddenly stop upon reaching the context of Carlyle. Marek Adamiec indicates, for example, thought-provoking coincidences regarding the construction of the eponymous hero in Norwid's novella and in Żywot i myśli Zygmunta Podfilipskiego by Józef Weyssenhoff, ${ }^{43}$ who was supposedly inspired by the aforementioned Polish translation of Sartor Resartus by Sygurd Wiśniowski. ${ }^{44}$

42 A. KADYJEWSKA, 'Ś w i a t a-t e g o książę'. O Norwidowskich obliczach szatana, "Studia Norwidiana" 17-18 (1999-2000), pp. 21-48.

43 M. ADAMIEC, Tajemnica lorda Singelworth albo metafizyka balonu, "Studia Norwidiana" 3-4 (1985-1986), p. 202.

44 Just like Teufelsdröckh drafts his treatise on sartorial philosophy, Podfilipski writes the study Le Franc-Parler d'un Gentilhomme. As indicated by Irena Szypowska, “introducing an original, 'scientific' treatise by Podfilipski into the novel is also a technique that reveals the ironic attitude of the narrator. Le Franc-Parler d'un Gentilhomme in fact confirms the protagonist's intellectual level, proving his ignorance and superficiality as a 'philosopher'." I. SzYPOWsKA, 'Przewrotny panegiryk'. Autokompromitacja bohatera, [in:] IDEM, Weyssenhoff, Warszawa 1976, p. 92. 
As Wiśniowski wrote two years after Carlyle's death, "he was undeniably a phenomenal man and author." ${ }^{45}$ Norwid must have also regarded him as a great personality, a thinker with whom one can fruitfully debate on the subject of his sartorial philosophy, especially when Norwid was writing Tajemnica... However, when he was composing Promethidion (and being barely thirty) he would oppose Carlyle's sartorial philosophy, which expresses a deeply secular metaphysics, with his own uncompromising "philosophy of Jesus's robes" as is indirectly yet clearly indicated by the dialogue Wiesław. Although it was merely an intuition, not fully developed across the entire dialogue, which acquired its general shape only in a footnote to the poem, already in this form it would perfectly convey the polemic temperament of the young Norwid, who would condemn with outrage - already as a young man, it seems - the world seen through the glasses of Carlyle or Teufelsdröckh, smudged with "God-born devil's excrements."

\section{REFERENCES}

Bratkowski S., Wstepp, [in:] R.W. Emerson, Eseje, trans. A. Tretiak, vol. 1, Lublin 1997, pp. 5-28.

Brzozowski S., Literatury zachodnie, [in:] IDEM, Legenda Młodej Polski. Studia o strukturze duszy kulturalnej. Redakcja II, vol. 1: eds. J. Bahr, S. Góra; vol. 2: ed. T. Podoska, Kraków 1997.

Brzozowski S., Polskie Oberammergau, [in:] Legenda Młodej Polski. Studia o strukturze duszy kulturalnej, vol. 1.

Brzozowski S., Wobec literatury rosyjskiej, [in:] Legenda Młodej Polski, vol. 2.

BurdziEj B., 'Wedle rozmaitości zmiennej kalendarza”. Norwid 'przemyślony', "Studia Norwidiana" 34: 2016, pp. 187-227.

Carlyle T., Sartor Resartus. On heroes, hero worship, London 1948.

CARlyle T., Sartor Resartus. Życie i zdania Pana Teufelsdröckha $w$ trzech księgach, trans. S. Wiśniowski, Warszawa 1882.

Corliss JR. F., Norwid and the American Transcendentalists, [in:] Cyprian Norwid. 18211883. Poet, thinker, craftsman. A centennial conference, eds. B. Mazur, G. Gömöri, London 1988.

Dambek-Giallelis Z., Tajemnice 'Tajemnicy lorda Singelworth', "Studia Norwidiana" 35: 2017, pp. 185-198.

GöмöRi G., Cyprian Norwid's Image of England and America, "The Polish Review” 46 (2001), no. 3, pp. 271-281.

Hugo V., Les Misérables, [in:] IDEM, The Essential Victor Hugo, trans. E.H. Blackmore, A.M. Blackmore, Oxford 2004.

${ }^{45}$ S. WIŚNIOWsKI, Charakter i pisma, p. 50. 
Halkiewicz-Sojak G., Norwidowska legenda o Byronie. Refleksy legendy w innych utworach Norwida, [in:] IDEM, Byron w twórczości Norwida, Toruń 1994, pp. 106-117.

KadyjewsKa A., 'Świata - tego książę'. O Norwidowskich obliczach szatana, "Studia Norwidiana" 17-18: 1999-2000, pp. 21-48.

LijewsKa E., Kuzynki Norwida. Euphemia Tudor Kleczkowska i Ketty Kleczkowska-Kierkpatrick, "Studia Norwidiana" 34: 2016, pp. 169-185.

MaŁecka A., Carlylean inspirations in Polish modernist philosophy, Kraków 1993.

Norwid C., Poems, translated from the Polish by Danuta Borchardt in collaboration with Agata Brajerska-Mazur, New York 2011.

Scherer-Virski O., The Modern Polish Short Story, Hague 1955.

SzYPOWSKa I., 'Przewrotny panegiryk'. Autokompromitacja bohatera, [in:] IDEM, Weyssenhoff, Warszawa 1976, pp. 92-96.

Trojanowiczowa Z., DambeK Z., Kalendarz życia i twórczości Cypriana Norwida, vol. 1: 1821- 1860, Poznań 2007.

TRYbuś K., Maska lorda Singelworth, "Studia Norwidiana” 14 (1996), pp. 95-103.

Wiśniowski S., Charakter i pisma Tomasza Carlyle'a, "Ateneum. Pismo naukowe i literackie" 1 (1882), pp. 50-69, 269-297.

\section{SUMMARY}

Cyprian Norwid's attitude to the philosophy of clothes developed by Thomas Carlyle in Sartor Resartus may indeed be perceived only as an object of speculation, but undoubtedly the author of Vade-mecum must have been familiar with him (as confirmed in his lectures on Juliusz Słowacki). This article outlines two areas of potential intertextual crossroads between Norwid's literary motives and the philosophy of life espoused by the legendary Carlyle: one is delimited by the poem Promethidion and a passage from the dialogue Wiesław, which may constitute a polemic with Carlyle's sartorial philosophy, while another is delineated by Lord Singelworth's Secret, where the figure and attitude of Singelworth may reveal the eccentricities of Carlyle himself, which is corroborated after Carlyle's death in 1881, when Norwid began to write his so-called Italian novelettes.

Keywords: Cyprian Norwid; Thomas Carlyle; Sartor Resartus; Promethidion; Lord Singelworth's Secret

Karol SAMSEL is assistant professor in the Institute of Polish Literature at the Faculty of Polish Studies at the University of Warsaw, where he is head of the Study Unit for the History of Drama in the years 1795-1939. He published in Prace Filologiczne, Pamiętnik Literacki, Studia Norwidiana, and the Yearbook of Conrad Studies (Poland). He is also author of the monograph Norwid - Conrad. Epika w perspektywie modernizmu (Warsaw 2015) and Inwalida intencji. Studia o Norwidzie (Warszawa 2017). 